\title{
Geodynamics of Dikes in North of Saveh
}

\author{
Mohammad-Hasan Bazoobandi', Mohammad-Ali Arian ${ }^{*}{ }^{*}$, Mohammad-Hashem Emami², \\ Gholam-Reza Tajbakhsh ${ }^{3}$, Abdollah Yazdi ${ }^{4}$ \\ ${ }^{1}$ Department of Geology, Faculty of Science, North Tehran Branch, Islamic Azad University, Tehran, Iran \\ ${ }^{2}$ Department of Geology, Faculty of Science, Islamshahr Branch, Islamic Azad University, Tehran, Iran \\ ${ }^{3}$ Department of Geology, Faculty of Science, Yazd University, Yazd, Iran \\ ${ }^{4}$ Department of Geology, Faculty of Science, Kahnooj Branch, Islamic Azad University, Kerman, Iran \\ Email: ${ }^{*}$ maa1361@yahoo.com
}

Received 8 July 2015; accepted 20 September 2015; published 23 September 2015

Copyright (C) 2015 by authors and Scientific Research Publishing Inc.

This work is licensed under the Creative Commons Attribution International License (CC BY).

http://creativecommons.org/licenses/by/4.0/

\section{cC) (i) Open Access}

\section{Abstract}

Dikes can be divided into sheeted, feeder, cone and swarm types based on the origin and the formation. A group of dikes that are formed in dense in a relatively broad zone influenced by a particular tectonic regime are referred to as swarm dikes. Swarm dikes have numerous applications such as locating mantle plume centers, determining areas of longstanding tensions and detection of deformation networks. The purpose of this article is classified swarm dikes of "North of Saveh" based on previous studies. In one study, swarm dikes are classified based on their initial geometry into five types of I, II, III, IV and V. According to this classification, our study has been shown that the dikes in north of Saveh are of type IV. In another study, the swarm dikes are classified into three types: parallel, large radial and small radial. According to the classification, our study has been shown that the dikes of North Saveh are parallel that have arisen by tensions caused by the collision of the Arabian plate and the Central Iran plate. In addition to original tensions in the region, local faults have been effective on the arrangement and the establishment of dikes.

\section{Keywords}

Swarm Dikes, Locating Mantle Plume, Dikes in North of Saveh, Dikes Classification

\section{Introduction}

Dikes are igneous structures intruded in the host rocks. Thus, they can be used to study and evaluate the tectonic environment, old tensions, and magmatism in the area. Dikes can be divided based on various criteria such as the origin and the formation. Some of them are known as sheeted dikes in ophiolitic complex. These dikes are formed at the conduit of magma ascent that forms pillow lava. Another group of dikes are formed in a relatively Corresponding author. 
broad zone influenced by a particular tectonic regime and in bulk and in dense in a region that is referred to as swarm dikes. In some cases, these dikes play roles in volcanic states, as a feeder dike of volcanic zones or dacitic and rhyolitic domes. This type of dikes is called feeder dikes. If the dikes are found in a wide area with a size of 10 thousand to 100 thousand square kilometers, they are called large swarm dikes [1]. Swarm dikes can be found in various parts of the world including northern part of Saveh, Iran, which is geologically located at the tectono-magmatic belt of Uromieh-Dokhtar. In this paper, in addition to introducing the dikes, the general characteristics and functions of them are studied.

\section{Geological Setting}

The study area is in the northern part of Saveh that located between the east longitudes of $50^{\circ} 15^{\prime}$ to $50^{\circ} 50^{\prime}$ and north latitudes of $35^{\circ} 00^{\prime}$ to $35^{\circ} 15^{\prime}$, and geologically, it is a small part of the Iranian central zone located at the volcanic belt of Uromieh-Dokhtar. Volcanic activity at the belt started from the Cretaceous and reached its peak during the Eocene that most of Iranian geologists believe that it started the activities from the lower Eocene [2]. Outcrops of the study area dated back to the Cenozoic and older rocks of the area are not sticking out of ground. Eocene rock units cover much of the area and, in general, are of volcanic types with sedimentary layers. In the area due to the influx of intrusive masses, dikes and high displacement caused by shear-stress fault, Eocene volcanic units have been completely disrupted, so that differentiation of rock units is hardly possible. Swarm dikes show in Figure 1 and Figure 2.

\section{General Features and Classification of Swarm Dikes}

A group of dikes formed in a relatively large area and under the influence of a specific tectonic regime and in dense and bulk are referred to as swarm dikes. These dikes are found at different scales across the world. Their size varies from a few kilometers to a few hundred square kilometers. Their length varies from hundreds to thousands of kilometers and their width varies from 10 to 50 meters. However, in some cases, the width has also been reported up to 200 meters. MacKenzie swarm dikes located at the north of America north in an area of over one hundred square kilometers are the largest. These dikes are giant swarm dikes [1]. They believe that factors like tectonic stress direction, uniformity, or anisotropy of the host rock and faults in the region are effective on deployment, dimensions and local direction of dikes. Ernest et al. have divided giant swarm dikes based on their initial geometry to the five types shown in Figure 3 [1].

Dikes shown as type I, II and III are convergent. These dikes diverge at a point at the center of mantle plume which is shown with the sign $\star$. Thus, they are extending radially around the mantle plume and show linear pattern at distances away from the center of the plume.

Swarm dikes of types I and II show the fan pattern. Type I is known as continuous fan and type II is known as separated fan.

Swarm dikes of type III are as semi-parallel dikes converged to a triple junction. These dikes create triple junction at tectonic position. On the differences between the dikes of type III and the dikes of type I and II, it can be said that for dikes of type III:

1) The magma chamber is located at the focal area influencing the separation between the semi-parallel dikes;

2) The evolution of rift basins is effective in the formation of semi-parallel swarm dikes;

3) Topographic figure of the uplift is the primary factor controlling the dike changes and their distribution in the region.

Swarm dikes of types IV and V show a linear pattern. Type IV spreads in a relatively wide range and type V is limited to a relatively narrow area.

Gutting Hou divided swarm dikes of northern China into three types:

1) Small radial dikes (a);

2) Large radial dikes (b);

3) Parallel swarm dikes (c) [3] (Figure 4).

\section{The Uses of Swarm Dikes}

\subsection{Locating Centers of Mantle Plume}

Distribution of volcanic rocks and intrusive masses located around the focal area of plume can be to locate areas 


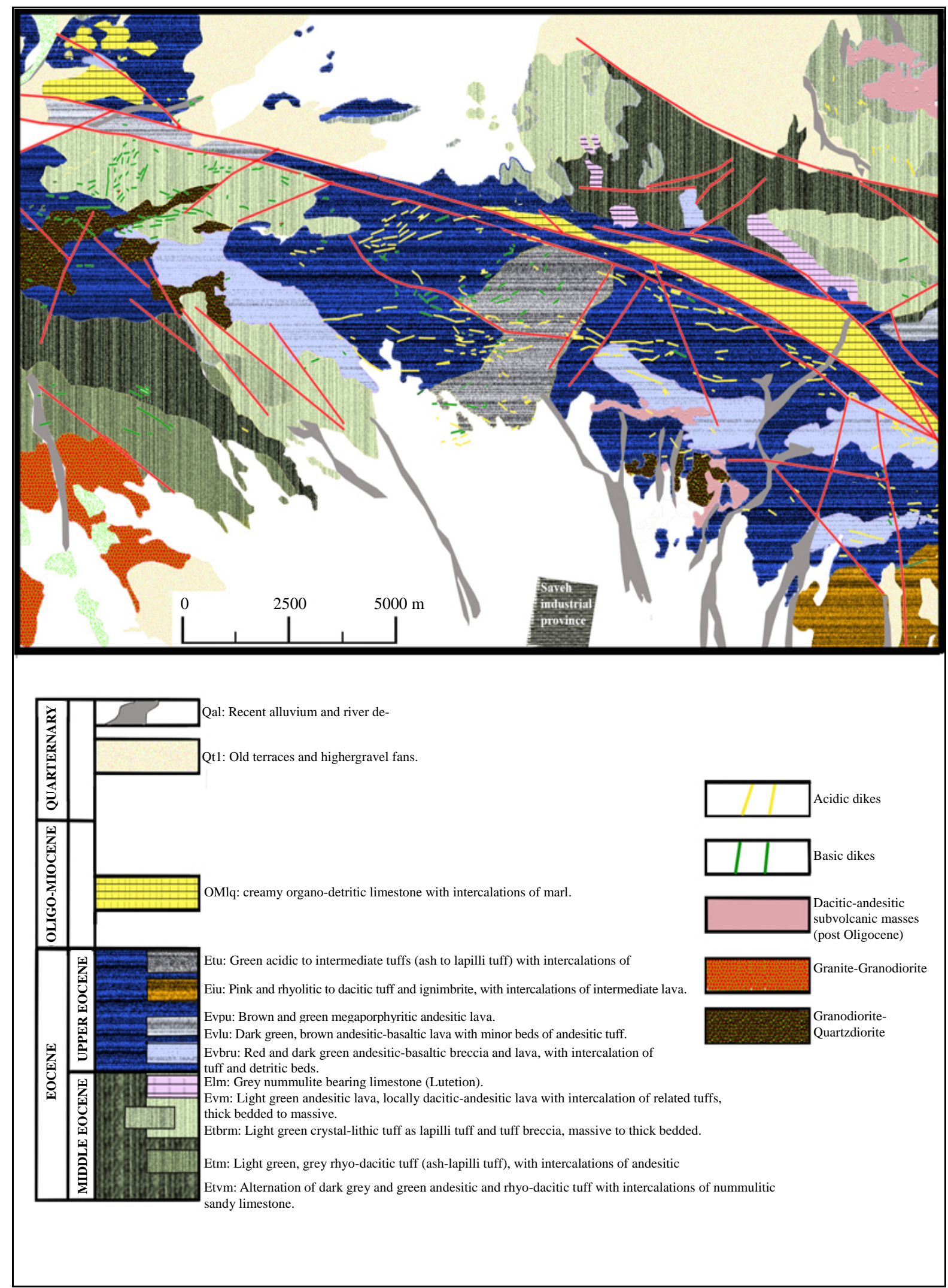

Figure 1. A part of simplified geological map of Saveh and location of dikes [4]. 


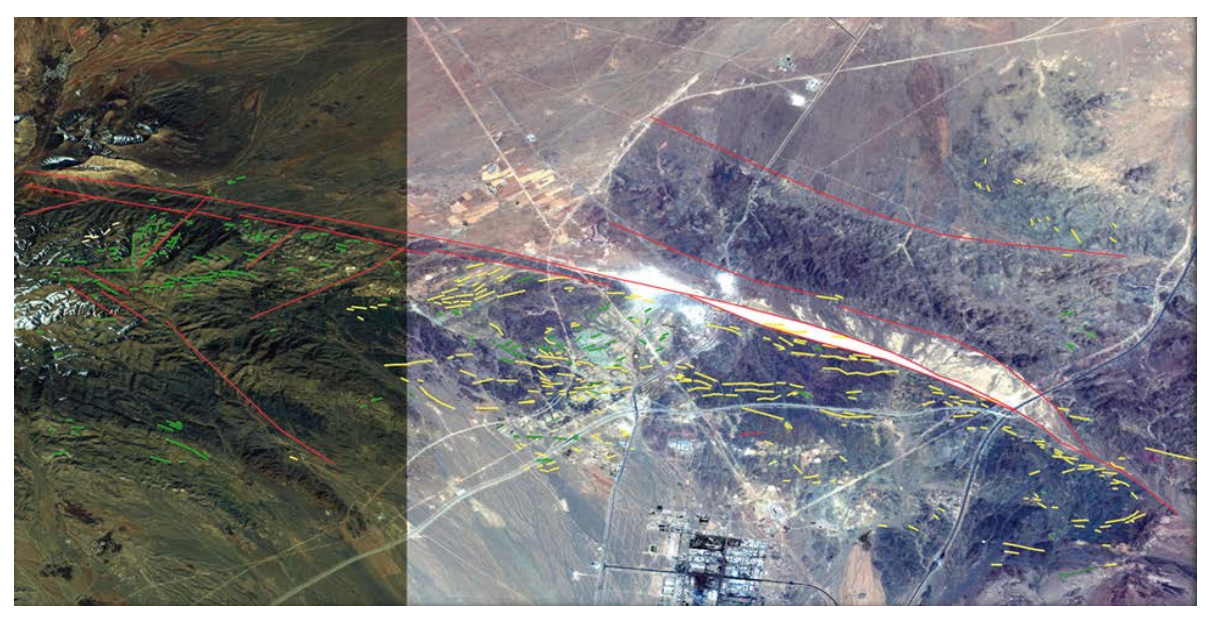

Figure 2. Dikes of north Saveh on the satellite image.

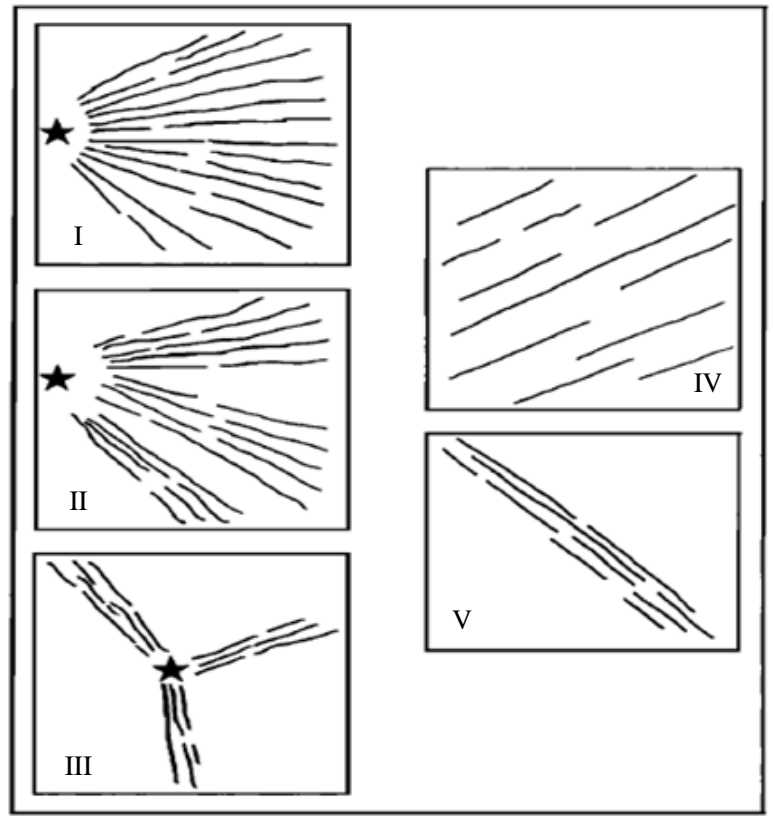

Figure 3. Classification of swarm dikes [1].

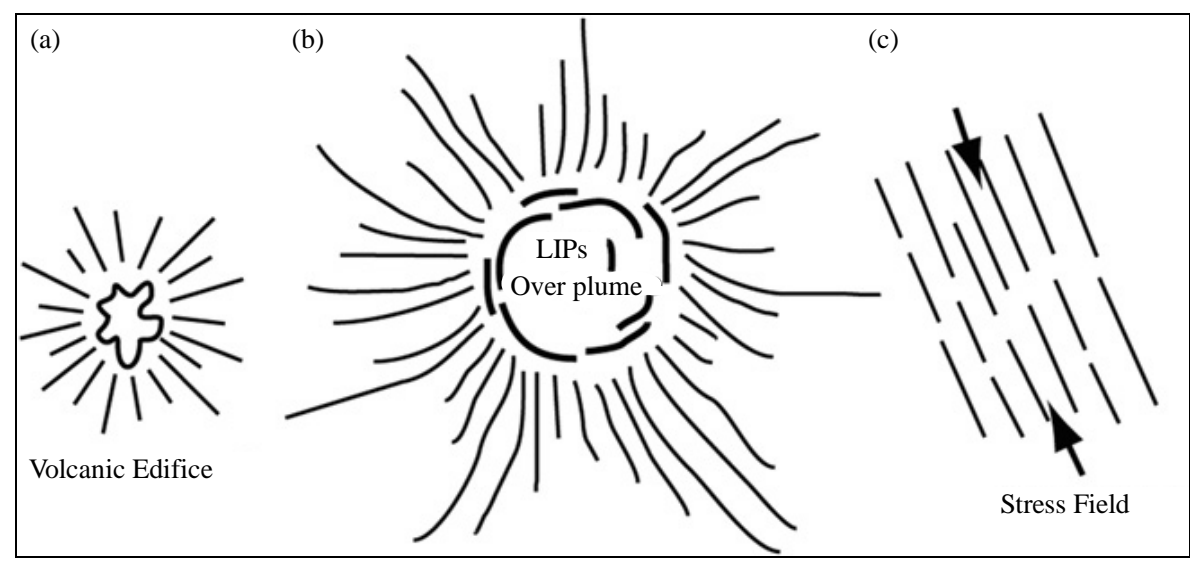

Figure 4. Classification of swarm dikes [3]. 
of mantle plume. However, it is coupled with some difficulties, due to subsequent changes caused by tectonic and orogenic processes on the rocks. However, since the dikes intrude into the stable cratons and are not later affected by orogenic changes, they can be used to locate mantle plumes more confidently [1]. They are used to locate mantle plumes of swarm radial dikes. This means that mantle plume location is specified by extending the dikes and finding the junction. This can be done by computer software.

\subsection{Detecting the Areas of Long-Standing Tension}

Most swarm dikes show a tilt and a deviation at regional scale. It may be a primary deviation resulted from the stress caused by the mantle plume as the dike intrudes into the host rock, or it is may be a secondary deviation, indicating the subsequent deformation is applied. Paleomagnetic studies that are sensitive to relative orientation help us diagnose primary or secondary deviations. Thus, according to the dike location and the tilt amount, past tension areas can be detected [1]. Dikes deployment in a relatively homogeneous and uniform structure means they are arranged in a direction perpendicular to the tensile stress [5]. Deployment pattern of swarm dikes is consistent with a linear pattern for the maximum compressive stress [6]. Parallel swarm dikes result from a local stress field such as mafic dikes of north China craton [7]. Parallel swarm dikes formation is associated with local stress field and local stress field is a very important factor in the distribution of parallel swarm dikes. Parallel swarm dikes are controlled by local stress field created at the border of tectonic sheets; therefore, they can be used to reconstruct the old local stress fields of cratons [3].

\subsection{Detecting Deformation Networks}

Deformation and tectonic processes disrupt the primary replacement pattern of large dikes. Thus restoring the original geometry of Swarm dikes can be used to determine the time and the type of the deformation and the tectonic processes, and finally to determine the deformation network.

\section{Swarm Dikes of North Saveh}

These dikes with approximate thickness of $0.4 \mathrm{~m}$ to $12 \mathrm{~m}$ and approximate length of $50 \mathrm{~m}$ to $3 \mathrm{~km}$ have been seen in the studied area. The number of them in that area is more than 250 dikes and their lithology consists of rhyolite, trachyte, trachyandesite, are andesite and andesibasalt. In the study area two types of dikes with acidic and basic compositions have outcrops. Basic dikes with higher frequency can be found in various parts of the area. In addition to the latest Eocene volcanic units, these dikes have cut Oligocene intrusive masses have and they are attributed to time after the Oligocene masses. Texture of the rocks is intersertal, porphiritic and doleritic. The composition of the main mineral of rocks is plagioclase (andesite-bytownite), pyroxene and very small amounts of alkali feldspar. Pyroxenes are mainly decomposed chlorite, epidote and carbonate minerals. Secondary minerals include apatite and opaque minerals. The rock name according to the mineralogical composition and texture is around andesite (Figure 5) and basalt. The composition of the rocks in chemical classification diagram of Cox et al. [8] is as trachyandesite (Figure 6).

Acidic dikes that are associated with subvolcanic intrusions have porphiritic and microgranular texture. The composition of main minerals consists of plagioclase, quartz, and in some cases, shape of biotite is unhedral to subhedral. The rock background is composed of quartz and feldspar. The composition of the rocks according to mineralogical characteristics is as the rhyodacite.

Swarm dikes of north Saveh have intruded in an area of approximately 100 square kilometers into Eocene volcanic rocks with andesitic and basaltic composition. This area is part of the magmatic arc of Uromieh-Dokhtar resulted from subduction of the Arabian plate beneath the central Iranian plate. Swarm dikes of north Saveh show a relatively regular and parallel linear arrangement that are generally in consistent with the direction of faults in the study area, and have the overall direction of northwest west-southeast. According to studies by Ernest $e$ al. [1], swarm dikes in north of Saveh that are part of swarm dikes of volcanic belt of Uromieh-Dokhtar can be considered as swarm dikes type IV, which are caused by the creation of the local stress fields. According to Hou et al. [7] and Hou [3] dikes of the area can be considered similar to parallel dikes and they call them parallel swarm dikes with linear pattern that have arisen within a relatively wide range and under the influence of local stress caused by a phenomenon such as subduction. 


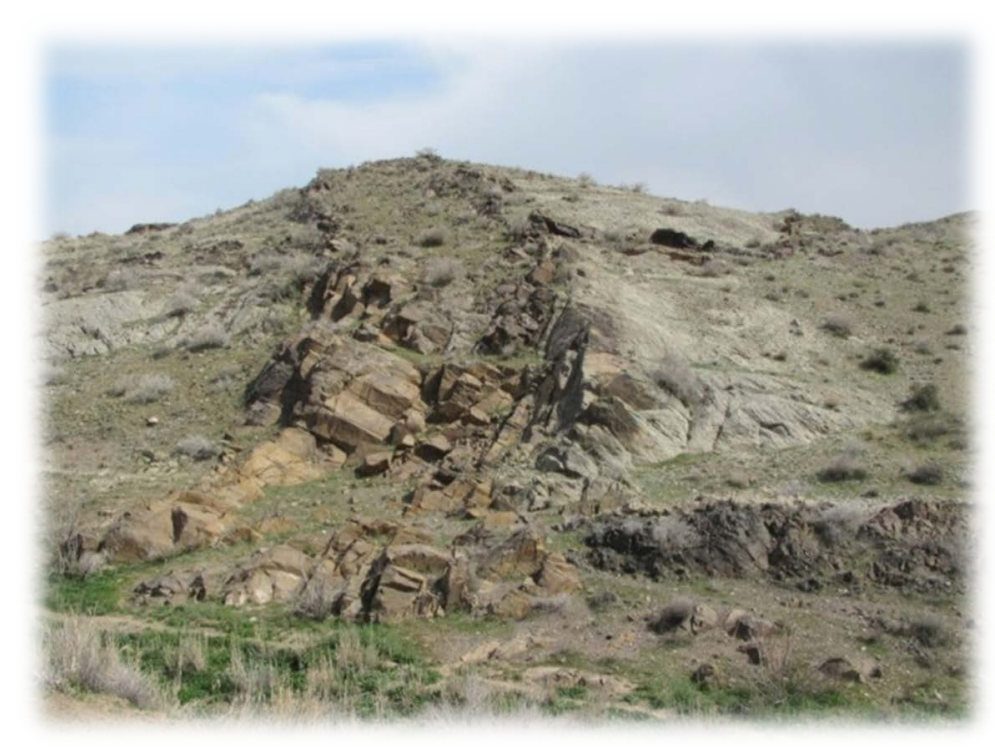

Figure 5. Andesitic dikes.

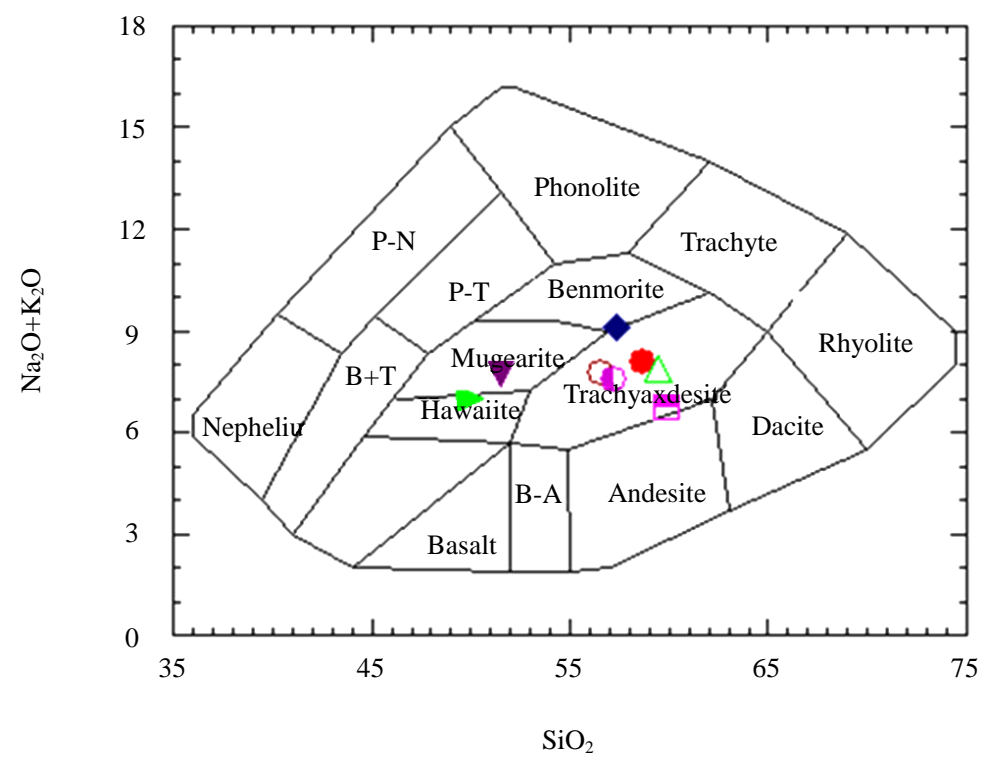

Figure 6. The composition of dikes [8].

According to the research carried out by Takin [9], Berberian [10], Emami [2], Moein-Vaziri [11] and Bouzari and Emami [12], the subduction at the magmatic belt of Uromieh-Dokhtar is related to the neoteric oceanic crust subduction and collision of central Iranian plate and Arabian plate from the Upper Cretaceous to Pliocene. According to Emami [2], the shear tectonic that is caused by subduction of Tethys oceanic crust beneath central Iran in the late Mesozoic in the zone of Uromieh-Dokhtar, has provided stress space and lava has stretched out. Uromieh-Dokhtar volcanic zone has been cut and replaced by northwest-southeast trend, faults with trends of north, northwest-south, southeast, such as Dehshir, Qom-Zefreh, Bidehend and South Saveh fault systems. These faults are interpreted as extensional fracture in a kinetic shear system.

Bouzari and Emami [12] believe that the opening of the Red Sea and application of compressive force in the late Neogene to the north has resulted in a counterclockwise rotational motion of Qom-Aran fault.

A structural analysis by Rajabiyoun and Mohajjel [13] on the faults and dykes in the belt, they described trends and proposed an trans-compressive deformation regime with larger compressive components than shear 


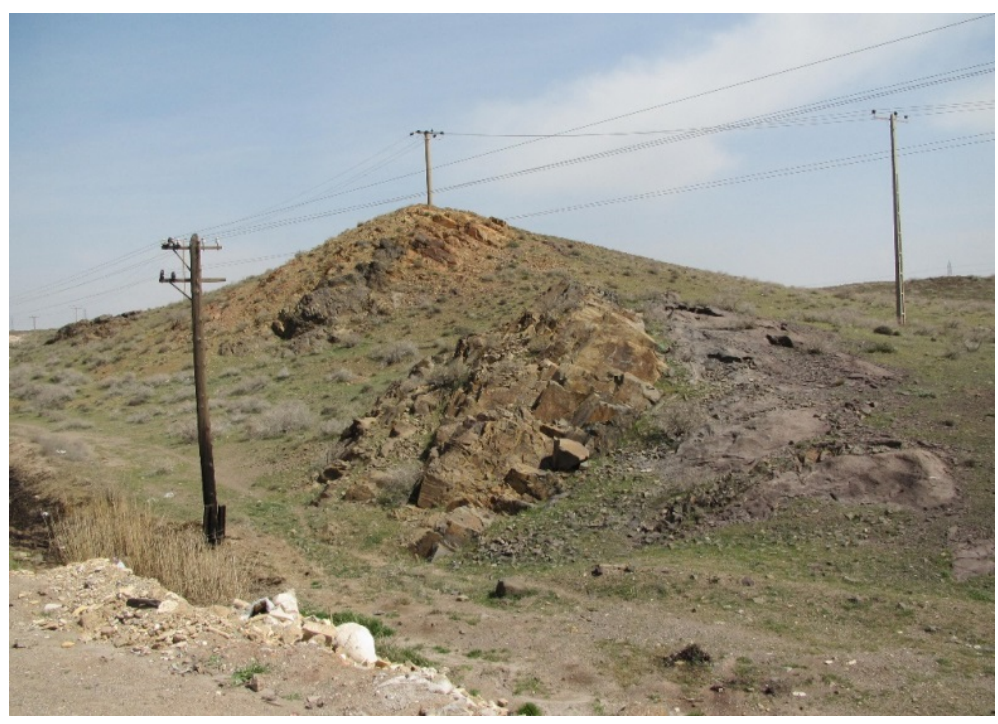

Figure 7. The secondary deviation.

component based on the geometric and kinematic characteristics of structural elements such as faults and dikes in the area.

Central Iran in the Eocene has influenced by significant stretching. Consequently, horst and graben have been moved and intense volcanic activity has been resulted [14]. In the late Eocene and the early Oligocene, orogenic movements of Pyrenean phase has resulted in the rise of intrusive masses [4]. Swarm mafic dikes for known as tectonic signs of stress zones [3]. However, are associated with the felsic dikes in the study area.

Most swarm dikes show a tilt and a deviation at regional scale. It may be a primary deviation resulted from the stress imposed as the dike intrudes into the host rock, or it is may be a secondary deviation, indicating the subsequent deformation is applied [15]. In addition to the primary tilt affected by the primary stress of the area, dikes of north Saveh show the tilt caused by the impact of faults occurring after the dikes emplacement (Figure 7).

\section{Conclusions}

Dikes in north of Saveh have intruded into tertiary volcanic rocks of magmatic Uromieh-Dokhtar zone. Extensive magmatic activity of this zone during Tertiary can be possibly related to the change from a compressional to extensional regime during and after Iranian-Arabian plate collision [16] [17]. Due to subducting Arabian Plate under Iranian Plate, the lithosphere has been partly melted and mixed with asthenosphere's magma and contamination crust.

In some places, they serve as feeder dikes and they have created dacitic domes and ignimbrite, the dikes can be used for analyzing old tensions and paleo sterss. Structural analysis of the dikes underscores the tension applied from the Southwest by Saudi Arabia plate on central Iran plate.

\section{References}

[1] Ernest, R.E., Buchan, K.L. and Palmer, H.C. (1995) Giant Dikes Warms, Characteristics, Distribution and Geotectonic Applications. In: Heimann, B.G., Ed., Physics and Chemistry of Dikes, Balkema, Rotterdam, 3-21.

[2] Emami, M.H. (1991) Geologic Map of Qom Quadrangle, Scale 1:250000.

[3] Hou, G.T. (2012) Mechanism for Three Types of Mafic Dyke Swarms. Geoscience Frontiers, 3, 217-223. http://dx.doi.org/10.1016/j.gsf.2011.10.003

[4] Ghalamghash, J. and Fonoudi, M. (1999) Geological Map of Saveh Area. Scale 1:100,000. Geological Survey of Iran.

[5] Pollard, D.D. (1987) Elementary Fractures Mechanics Applied to the Structural Interpretation of Dykes. In: Halls, H.C. and Fahrig, W.H., Eds., Mafic Dyke Swarms, Vol. 34, Geological Association of Canada, Canada, 112-128. Geological Association of Canada Special Paper.

[6] Hou, G.T., Li, J.H., Yang, M.H., Yao, W.H., Wang, C.C. and Wang, Y.X. (2008) Geochemical Constraints on the 
Tectonic Environment of the Late Paleoproterozoic Mafic Dykes Warms in the North China Craton. Gondwana Research, 13, 103-116

[7] Hou, G.T., Kusky, T.M., Wang, C.C. and Wang, Y.X. (2010) Mechanics of the Giant Radiating Mackenzie Dykes Warm: A Palaeo Stress Field Modeling. Journal of Geophysical Research, 115, 1-14.

[8] Cox, K.G., Bell, J.D. and Pankhurst, R. J. (1979) The Interpretation of Igneous Rocks. London University, London, 450 p. http://dx.doi.org/10.1007/978-94-017-3373-1

[9] Takin, M. (1971) Iranian Geology Anszeih Continental Drift in Middle East. Geological Survey, Iran, Note N81.

[10] Berberian, M. (1981) Tectono-Plutonic Episodes in Iran. In: Gupta, H.K. and Delany, F.M., Eds., Zagros, Hindu Kush, Himalaya: Geodynamic Evolution, Geodynamics Series 3, American Geophysical Union, 5-32. http://dx.doi.org/10.1029/GD003p0005

[11] Moein-Vaziri, H. (1996) An Introduction of Geology of Magmatism in Iran. Tehran University of Teacher Education, Tehran, 440.

[12] Boozari, S. and Emami, M.H. (2003) Qom-Aran Pattern of Structural Subsidence. Earth Sciences Research Journal, No. 49-50, 62-77.

[13] Rajabiyoun, J. and Mohajjel, M. (2003) Structural Analysis of Volcano-Sedimentary Deposits of Uromieh-Dokhtar zone in the Area of Tafresh, Evidence of Tectonic Transpression. Proceedings of the 22nd Meeting of Earth Sciences, Geology and Mineral Exploration Organization of Iran, Tehran, 2003, 78-91.

[14] Helmi, F. (1991) Lithological and Geochemical Study of Igneous Rocks in North West Saveh (North Nivesht). MS Thesis, University of Tehran, Tehran.

[15] Ernest, R.E., Head, J.W., Parfitt, E., Grosfils, E. and Wilson, L. (1995) Giant Radiating Dyke Swarms on Earth and Venus. Earth-Science Reviews, 39, 1-58. http://dx.doi.org/10.1016/0012-8252(95)00017-5

[16] Dilek, Y., Imamverdiyev, N. and Altunkaynak, S. (2009) Geochemistry and Tectonics of Cenozoic Volcanism in the Lesser Caucasus (Azerbaijan) and the Peri-Arabian Region: Collision-Induced Mantle Dynamics and Its Magmatic Fingerprint. International Geology Review, 52, 536-578. http://dx.doi.org/10.1080/00206810903360422

[17] Tajbakhsh, G., Emami, M.H., Moine-Vaziri, H. and Rashidnejad-Omran, N. (2012) Petrology, Geochemistry and Tectonomagmatic Settinng of Kaleybar Intrusion (Eastern Azarbaijan). 